\title{
Emerging roles of APLN and APELA in the physiology and pathology of the female reproductive system
}

\author{
Xueying Wang Equal first author, 1, 2 , Xiaofei Liu ${ }^{\text {Equal first author, } 1,2,{ }^{2} \text { Zifan Song }}{ }^{1}$, Xin Shen ${ }^{1}$, Siying Lu ${ }^{1}$, Yan Ling ${ }^{\text {Corresp., } 3}$, Haibin \\ Kuang ${ }^{\text {corresp. } 1,4}$ \\ ${ }^{1}$ Department of Physiology, Basic Medical College, Nanchang University, Nanchang, China \\ Department of Clinical medicine, School of Queen Mary, Nanchang University, Nanchang, China \\ 3 Department of Obstetrics and Gynecology, Jiangxi provincial People's Hospital affiliated Nanchang University, Nanchang, China \\ 4 Jiangxi Provincial Key Laboratory of Reproductive Physiology and Pathology, Medical Experimental Teaching Center of Nanchang University, Nanchang, \\ China
}

Corresponding Authors: Yan Ling, Haibin Kuang

Email address: lingyan1205@163.com, kuanghaibin@ncu.edu.cn

APLN, APELA and their common receptor APLNR (composing the apelinergic axis) have been described in various species with extensive body distribution and multiple physiological functions. Recent studies have witnessed emerging intracellular cascades triggered by APLN and APELA which play crucial roles in female reproductive organs, including hypothalamus-pituitary-gonadal axis, ovary, oviduct, uterus and placenta. However, a comprehensive summary of APLN and APELA roles in physiology and pathology of female reproductive system has not been reported to date. In this review, we aim to concentrate on the general characteristics of APLN and APELA, as well as their specific physiological roles in female reproductive system. Meanwhile, the pathological contexts of apelinergic axis dysregulation in the obstetrics and gynecology are also summarized here, suggesting its potential prospect as a diagnostic biomarker and/or therapeutic intervention in the polycystic ovary syndrome, ovarian cancer, preeclampsia and gestational diabetes mellitus. 


\section{Emerging roles of APLN and APELA in the physiology and}

\section{2 pathology of the female reproductive system}

3 Xueying Wang ${ }^{1,2 \uparrow}$, Xiaofei Liu ${ }^{1,2 \dagger}$, ZiFan Song ${ }^{1}$, Xin Shen ${ }^{1}$, Siying Lu ${ }^{1}$, Yan Ling ${ }^{3, *}$, Haibin

4 Kuang ${ }^{1,4, *}$

$5 \quad{ }^{1}$ Department of Physiology, Basic Medical College, Nanchang University, Nanchang, China

$6 \quad{ }^{2}$ Department of Clinical medicine, School of Queen Mary, Nanchang University, Nanchang,

7 China

8 32Department of Obstetrics and Gynecology, Jiangxi provincial People's Hospital affiliated

9 Nanchang University, Nanchang, China

10 4Jiangxi Provincial Key Laboratory of Reproductive Physiology and Pathology, Medical

11 Experimental Teaching Center of Nanchang University, Nanchang, China

12

†These authors' contributed equally to this work.

\section{*Corresponding authors:}

16 Haibin Kuang, Professor, Ph.D., Department of Physiology, Basic Medical College, Nanchang

17 University, Nanchang, Jiangxi 330006, PR China. Telephone and Fax: 86-791-83827148, E18 mail: kuanghaibin@ncu.edu.cn

Yan Ling, Professor, Department of Obstetrics and Gynecology, Jiangxi provincial People's

China. Telephone: 86-791-86895550, Fax: 86-791-86895863 E-mail: lingyan1205@163.com

Xueying Wang: jp6303416254@qmul.ac.uk

26 Xiaofei Liu: liuxf3389@163.com

27 Zifan Song: $\quad$ 1214680710@qq.com

28 Xin Shen: $\quad$ 1694915656@qq.com

29 Siying Lu: $\quad$ 892403767@qq.com

30 Yan Ling: lingyan1205@163.com

31 Haibin Kuang: kuanghaibin@ncu.edu.cn 


\section{Abstract:}

34 APLN, APELA and their common receptor APLNR (composing the apelinergic axis) have been 35 described in various species with extensive body distribution and multiple physiological

36 functions. Recent studies have witnessed emerging intracellular cascades triggered by APLN and

37 APELA which play crucial roles in female reproductive organs, including hypothalamus-

38 pituitary-gonadal axis, ovary, oviduct, uterus and placenta. However, a comprehensive summary

39 of APLN and APELA roles in physiology and pathology of female reproductive system has not

40 been reported to date. In this review, we aim to concentrate on the general characteristics of

41 APLN and APELA, as well as their specific physiological roles in female reproductive system.

42 Meanwhile, the pathological contexts of apelinergic axis dysregulation in the obstetrics and

43 gynecology are also summarized here, suggesting its potential prospect as a diagnostic biomarker

$44 \mathrm{and} /$ or therapeutic intervention in the polycystic ovary syndrome, ovarian cancer, preeclampsia

45 and gestational diabetes mellitus. 


\section{6 \\ Main article text}

47

48

49

50

51

52

53

54

55

56

57

58

59

60

61

62

63

64

65

66

67

68

69

70

71

72

73

74

75

76

\section{7}

78

79

80

81

\section{Introduction}

Apelin receptor (APLNR, also known as APJ, APJR, AGTRL1 and HG11) was firstly identified as a class A G protein-coupled receptor in 1993. It consists of 380 amino acids, which has a sequence sharing $31 \%$ homology with that of the angiotensin type 1 receptor (O'Dowd et al., 1993). Nevertheless, APLNR cannot actually bind to angiotensin II and remains as an "orphan receptor" until its endogenous ligand apelin (APLN, also named APEL and XNPEP2) was later extracted from bovine stomach (Tatemoto et al., 1998). APLN is generally existed in functional isoforms which are cleaved and modified from the C-terminus of a 77-amino acid pre-propeptide encoded by APLN gene, with different affinities for APLNR and prevalent distribution (Chapman, Dupré \& Rainey, 2014). Both APLN and its receptor APLNR levels are universally high at multiple organs like brain, retina, heart, stomach, liver, kidney and blood vessels in many species (Kawamata et al., 2001; Zeng et al., 2007; Kasai et al., 2008; Qian et al., 2011; Krist et al., 2013; Lv et al., 2017). Recent years, apelin receptor early endogenous ligand (APELA, also named ELABELA, Toddler and Ende) was identified as a new endogenous ligand for APLNR in both Chng and Pauli's labs independently (Chng et al., 2013; Pauli et al., 2014). Similar to APLN, this 54-amino acid polypeptide is also processed into several isoforms. APELA is highly enriched in the early stage of embryo and confirmed to play a vital role in embryogenesis and angiogenesis (Norris et al., 2017). APLNR and its two ligands compose the apelinergic axis, which is well delineated in systemic physiological processes like cardiogenesis, angiogenesis, fluid homeostasis, vasodilation and energy metabolism.

More recently, several studies have been investigating the possible intervention of apelinergic axis in female reproductive system based on its precise regulation of steroidogenesis, angiogenesis and vasodilation, before moving onto the dysregulation of this system which hypothetically causes fertility disorders and pregnancy complications like polycystic ovary syndrome (PCOS), ovarian cancer, gestational diabetes mellitus (GDM) and preeclampsia (PE) (summarized in Table 1). This review summarizes and evaluates the current role of apelinergic system in female reproductive system at both physiological and pathological profiles (Fig 1), as well as providing the direction for future research.

\section{Survey methodology}

Recently published articles and reports (within 15 years) were conducted from PubMed, Google Scholar and Queen Mary Library databases. Based on the keywords 'APLN', 'APELA' and 'female reproduction', articles extracted were summarized to identify the physiological and pathological roles of apelinergic axis in female reproductive system. This study was approved by

Peer) reviewing PDF | (2020:05:48913:2:0:NEW 20 Sep 2020) 
82 Jiangxi Provincial Key Laboratory of Reproductive Physiology and Pathology, Medical

83 Experimental Teaching Center of Nanchang University.

84

85

86

87

88

89

90

91

92

93

94

95

96

97

98

99

100

101

102

103

104

105

106

107

108

109

110

111

112

113

114

115

116

117

118

119

\section{APLN and APELA, endogenous ligands of APLNR}

\subsection{Characteristics of APLN}

Human APLN gene is located on chromosome Xq25-26.1 which encodes a pre-propeptide of 77 amino acids. After cleavage of the 22-amino acid secretory sequence at $\mathrm{N}$ terminus by endopeptidases, the propeptide is subsequently processed into three active fragments at several dibasic residues (Arg-Lys and Arg-Arg), including APLN-36, APLN-17 and APLN-13. APLN13 undergoes post-transcriptional cyclization at the N-terminal glutamine, generating pyroglutamate-APLN-13 (Pyr1-APLN-13) (Tatemoto et al., 1998). The potency and efficacy of APLN differ from different isoforms. For instance, APLN-36, APLN-13 and Pyr1-APLN-13 are preponderantly contributed in human cardiovascular regulation (Maguire et al., 2009), whereas APLN-17 plays crucial role in APLNR internalization (El Messari et al., 2004). To date, APLN is abundantly distributed in female reproductive system such as ovary, oviduct, uterus and placenta. Emphatically, APLN is identified as one type of adipokines secreted by white adipose tissue, which plays a role with other adipokines in regulating the secretion of gonadotropin releasing hormone $(\mathrm{GnRH})$, gonadotropins and steroids through hypothalamo-pituitary-gonadal (HPG) axis (Bertrand, Valet \& Castan-Laurell, 2015; Yang et al., 2019).

\subsection{APLN dependent signaling pathway}

APLN/APLNR activates different types of $G$ protein and further stimulates three important signaling pathways, which are phosphorylation of phosphoinositide 3-kinase/protein kinase B (PI3K/Akt), reduction of cyclic adenosine monophosphate (cAMP) and activation of phospholipase C- $\beta$ (PLC- $\beta$ ), respectively (Fig 2 A) (Chapman, Dupré \& Rainey, 2014). There are two types of pertussis toxin-sensitive $\mathrm{G} \alpha$ protein $(\mathrm{G} \alpha \mathrm{i} / \mathrm{o}, \mathrm{G} \alpha \mathrm{q} / 11)$ at the downstream of APLNR, mediating different signaling transduction (Masri et al., 2002). Gai/o activates PI3K/Akt dependent manner which is crucial for cell survival and nitric oxide (NO) induced vasodilation (Liu et al., 2010). Akt phosphorylates Bcl-2-associated death promoter (Bad, a BH3-only protein) and shifts it to an inert form, which inhibits the binding of Bad and Bcl-2. Bcl-2 plays an anti-apoptotic role by disturbing the aggregation of Bak and Bax (BH123 proteins) in the mitochondrial outer membrane, and thereby attenuating the release of cytochrome $\mathrm{c}$ and activation of caspase-3 (Liu et al., 2019). Moreover, endothelial nitric oxide synthase (eNOS) can also be activated by Akt through phosphorylation, triggering the release of NO for vasodilation (Fig 2 A) (Yang et al., 2014). Additionally, Gai/o inhibits adenylate cyclase (AC), following with the reduction of 3', 5'- cAMP and protein kinase A (PKA), which could potentially regulate the glucose homeostasis (Fig 2 A) (Masri et al., 2002). Gaq/11 activates PLC- $\beta$ hydrolyze phosphatidylinositol 4, 5-bisphosphate into second messengers diacylglycerol and inositol trisphosphate, which increases the release of calcium $\left(\mathrm{Ca}^{2+}\right)$ from intracellular store 
120 and activates protein kinase $\mathrm{C}$ (PKC) (Carpéné et al., 2007). Amplified intracellular $\mathrm{Ca}^{2+}$ not

121 only mediates positive inotropic effect in cardiac smooth muscle, but also stimulates NO release

122 in periphery via activating eNOS by calmodulin (Dai, Ramirez-Correa \& Gao, 2006). PKC in

123 turn activates Ras/MAPK system, which plays a crucial role in cell proliferation (Szokodi et al.,

124 2002). Furthermore, MAPK halts the expression of pro-oxidant enzymes and subsequently

125 attenuates the release of reactive oxygen species (ROS), which suppresses lipid metabolism and

126 inflammatory reaction (Fig 2 A) (Than et al., 2014).

127

$128 \quad 3.3$ Characteristics of APELA

129 Apela gene, located on chromosome 4 of Homo sapiens (Fagerberg et al., 2014) (chromosome 8

130 in Mus musculus (Yue et al., 2014) and chromosome 1 in Danio rerio (Ulitsky et al., 2011), was

131 originally annotated to be transcribed exclusively into a non-coding RNA in zebrafish embryo

132 (Chng et al., 2013), while recently it was confirmed to encode a 54-amino acid precursor which

133 further undergoes proteolysis and generates four mature isoforms: APELA-32, APELA-22,

134 APELA-21 and APELA-11. The shortest isoform is conserved across vertebra species (Huang et

135 al., 2017). Compared with APLN, APELA as the second discovered endogenous ligand of

136 APLNR is also ubiquitously detected in placenta, heart, kidney, prostate and mammalian plasma

137 but not as widely as APLN (Wang et al., 2015). In addition, studies have reported that APELA is

138 highly expressed in human embryonic stem cells (hESCs) where the APLNR is absent,

139 indicating the existence of an alternative APLNR-independent transduction (Ho et al., 2015). A

140 recent report has suggested that an orphan $G$ protein-coupled receptor 25 (GPR25), associated

141 with blood pressure regulation and autoimmune disease, could be activated by both APLN and

142 APELA in non-vertebrates, which is similar as APLN in decreasing the intracellular cAMP level.

143 However, the accurate role of this putative receptor in vertebrate remains to be determined

144 (Zhang et al., 2018).

145

$146 \quad 3.4$ APELA dependent signaling pathway

147 Similar to APLN, APELA binds to APLNR, subsequently activating Gai/o and Gaq/11 mediated 148 signaling cascades, including PI3K/Akt, PKC and PKC-independent Ras/MAPK pathways (Fig

1492 A) (Perjés et al., 2016; Zhang et al., 2018). Nevertheless, it also plays non-redundant role for its

150 specific properties during embryo development. In mouse ESCs, Apela acts as a long non-coding

151 RNA that binds to heterogeneous nuclear ribonucleoprotein L (hnRNPL) at the 3' UTR, which

152 negatively regulates the interaction between p53 and hnRNPL, and promotes p53-mediated DNA

153 damage induced apoptosis (Fig 2 B) (Li et al., 2015). In hESCs, APELA acts as a paracrine

154 secreted hormone that binds to an alternative unknown receptor (non-APLNR) and activates

$155 \mathrm{PI} 3 \mathrm{~K} / \mathrm{AKT}$ signaling for cell survival and self-renewal. This process resembles other fibroblast

156 growth factor like exogenous insulin and endogenous insulin-like growth factors (IGFs) in PI3K-

157 mediated cell proliferation. However, APELA-pulsed hESCs is non-redundant as it also

158 implicates in mesendodermal linage commitment through a PI3K-independent manner (Ho et al.,

Peer] reviewing PDF | (2020:05:48913:2:0:NEW 20 Sep 2020) 
159 2015). During zebrafish gastrulation, a proper level of APELA acting as a mitogen, indirectly

160 mediates the internalization of ventrolateral mesendodermal cells. This process is presumably

161 achieved via activating NODAL/TGF $\beta$ signaling pathway (Fig 2 C), whereas its specific

162 mechanism remains unknown (Pauli et al., 2014).

163

164

165

166

167

168

169

170

171

172

173

174

175

176

177

178

179

180

181

182

183

184

185

186

187

188

189

190

191

192

193

194

195

\section{Roles of APLN and APELA in HPG axis}

Endocrine function of female reproduction initiates from hypothalamic GnRH neurons, which mainly receipt projections from arcuate, paraventricular, supraoptic and medial preoptic nuclei of hypothalamus. These neurons secrete $\mathrm{GnRH}$ in a pulsatile manner that favours the secretion of lutenizing hormone ( $\mathrm{LH}$ ) and follicle stimulating hormone (FSH) from gonadotroph cells in the anterior pituitary (Jin \& Yang, 2014). APLN and its receptor are intensively detected in the same nucleic group of the hypothalamus (Pope et al., 2012), indicating an essential behavior of them in reproductive regulation. It was reported in both intracerebroventricular and intraperitoneal infusion that APLN-13 suppressed the secretion of FSH and LH in frontal hypophysis in rats, but it cannot cause a disturbance at the GnRH level (Taheri et al., 2002; Tekin et al., 2017). The structural and functional similarities between APLN and GnRH (Cho et al., 2007) were reasonably suspected that APLN could be a competitive inhibitor in the adenohypophysis for GnRH receptors. In addition, the central action of APELA in hypothalamus was also demonstrated that it exerted as an anorexigenic hormone via binding to APLNR and activating arginine vasopressin and corticotropin releasing hormone neurons in the paraventricular nuclei (Santoso et al., 2015). Whether it has an effect on reproductive-dependent hormone or not remains to be illuminated.

\section{Roles of APLN and APELA in uterine appendages}

\subsection{Distribution and role of APLN in the ovarian follicle}

Under the normal physiological states, APLN has been identified as a steroidogenic regulator in ovaries of various species including bovine, mouse, rat, porcine, sheep and human (Roche et al., 2016, 2017; Shuang et al., 2016; Rak et al., 2017; Mercati et al., 2019). In cultured bovine follicles, it was firstly reported that $A P L N$ mRNA was not found in granulosa cells (GCs), whereas $A P L N R$ mRNA was detected and significantly stimulated by estradiol and progesterone in GCs of estrogen-inactive follicles. In interstitial theca cells, both $A P L N$ and its receptor mRNA were obviously expressed (Shimizu et al., 2009). Two years later, another group cultured bovine ovarian follicles at the similar condition, and found that estradiol over $5 \mathrm{ng} / \mathrm{ml}$ (evaluation for follicular maturation) stimulated the expression of APLN and APLNR in theca cells. However, it had no significant effect on the expression of APLN and APLNR in GCs (Schilffarth et al., 2009). Recent research confirmed that the expression level of APLN and APLNR were up-regulated in both GCs and oocytes, but remained constant in theca cells 
196 (Schilffarth et al., 2009; Shimizu et al., 2009; Roche et al., 2017). In vitro, APLN from GCs of

197 inactive follicles, in response to IGF1 but not to FSH, markedly increased the progesterone

198 production (Roche et al., 2017). In porcine follicles, elevated APLN and APLNR were detected

199 following the follicular growth. In turn, APLN significantly increased the secretion of basal

200 steroid hormone (progesterone and estradiol) through the activation of steroidogenic enzyme

201 (3ßHSD and CYP19A1) via AMPKa stimulation, whereas it also decreased the IGF1- and FSH-

202 induced steroid secretion (Rak et al., 2017).

203

204

205

\subsection{Role of APLN in corpus luteum (CL)}

As a potent angiogenic factor, apelinergic axis also plays a role in the transient luteal stage after

206 ovulation. It has been mentioned that this system exclusively exists in the bovine smooth muscle

207 of intraluteal arterioles, with ligands elevated from early to late $\mathrm{CL}$ and followed by a significant decrease at regressed CL, while receptors increased from early to mid CL and remained constant till regressed CL (Shirasuna et al., 2008). Paradoxically, another study showed that APLNR also decreased significantly after mid CL (Schilffarth et al., 2009). Luteolytic factor prostaglandin F2 $\alpha$ stimulates APLN and APLNR mRNA expression particularly at the periphery of mid CL (Shirasuna et al., 2008). In ewes, both APLN and APLNR proteins were observed in large luteal cells, and the highest level of APLN mRNA was detected in the luteal phase of the ovarian cycle compared to ewes in the anestrous one (Mercati et al., 2019). In porcine cultured CL, APLN stimulates $3 \beta \mathrm{HSD}$ activity, which converts inert 5-ene-3ßHSD to the active 4-ene-3-oxo steroid, therefore it has a pivotal role in progesterone biosynthesis, suggesting an auto/paracrine pattern

217 of the APLN/APLNR system in the ovary (Różycka et al., 2018). In human, this system is found in the whole ovary through different developmental stages, including luteinized human GCs, theca, oocytes and corona cumulus complex. In cultured luteinized human GCs and follicular fluid, IGF1 exclusively stimulates APLNR expression whereas LH and FSH cannot show the same effect. Conversely, recombinant human APLN-13 and -17 stimulates the secretion of both basal and IGF-induced progesterone and estradiol in a dose-dependent manner, and this process is significantly accelerated in response to IGF1 (Roche et al., 2016). This hormone regulation is in agreement to those discovered in bovine that demonstrated APLN could stimulate steroidogenesis and it is speculatively implemented via $3 \beta \mathrm{HSD}$ activation and Akt and MAPK3/1 signaling (Roche et al., 2016).

227

\subsection{Regulation of APLN in PCOS}

229

PCOS is a common gynecological endocrinopathy characterized by over-expressed LH triggered hyperandrogenism, chronic oligo/anovulation and polycystic ovaries morphology, with clinical manifestations described as "hirsutism, acne, irregular menstruation and subfertility" (Teede,

232 Deeks \& Moran, 2010; Teede et al., 2018). Despite of the positive correlation between PCOS 
234 Antoni, 2010), the definite aetiology of PCOS at the molecular level still need to be elucidated. It

235 is known that adipokines are bridges to link the energy metabolism and reproductive system,

236 thus they are probably implicated in this process. Hypothetically, APLN controls several aspects

237 of ovarian function in PCOS, underpinned by its role in steroid hormone regulation and insulin

238 resistance. Firstly, the concentration of APLN and its receptors were detected to be significantly

239 increased in PCOS patients with a positive correlation between follicle count and APLN levels

240 (Bongrani et al., 2019). This process could be explained by a steroid hormone disturbance effect

241 of APLN in HPG axis. Moreover, as mentioned above, the secretion of APLN in atretic follicles

242 is notably increased in response to IGF1 and insulin, and subsequently stimulates steroidogenesis

243 in GCs (Boucher et al., 2005; Roche et al., 2016). It indicates a possible implication of insulin in

244 APLN synthesis via activating PI3K/Akt and MAPK3/1 signaling pathways (Boucher et al.,

245 2005). Homeostatic Model Assessment for Insulin Resistance (HOMA-IR) and Body Mass Index

246 (BMI) as hall markers of PCOS have been confirmed to be associated with adipocytokines, even

247 if there is still an inconsistency among different researches. In normal cases, studies have

248 revealed either positive or negative correlations of APLN with HOMA-IR and BMI (Cekmez et

249 al., 2011; Olszanecka-Glinianowicz et al., 2015). In PCOS cases, several groups have shown an

250 enhanced level of serum APLN positively correlated with HOMA-IR and BMI (Sun et al., 2015;

251 Roche et al., 2016; Bongrani et al., 2019), while one research reported a decreased serum APLN

252 level which was positively associated with HOMA-IR and BMI (Altinkaya et al., 2014). These

253 discrepant findings among published literature may be attributed to the differences in research

254 design, different stages of PCOS, sample size, genetic characteristics of patients and APLN

255 evaluation methodology.

256

2575.4 Roles of APLN and APELA in ovarian cancer

258 Previous studies demonstrated that the level of APLN expression was significantly increased in

259 ovarian cancer cells. In MCF-7 cells, the APLN-APLNR system was involved in regulating the

260 proliferation and metastasis via phosphorylating ERK1/2 pathway (Peng et al., 2015). Secretion

261 and expression of APLN as a mitogenic factor was also detected in OVCAR3 cell line which

262 regulates the proliferation progress in a dose-dependent manner (Hoffmann, Fiedor \& Ptak,

263 2017). In SKOV3 cell line, over-expressed APLN and its receptor reduced the sensitivity of anti-

264 angiogenic therapeutic regimen (Masoumi et al., 2020). Recently, an elevated APELA level was

265 documented in various histotypes of ovarian cancers, especially in ovarian clear cell carcinoma

266 (OCCC) (Yi et al., 2017). It is speculated that APELA was involved in multiple pathways in

267 tumorigenesis. For instances, it accelerates cell mitosis and migration through activating ERK

268 and PI3K/AKT cascades (Ho et al., 2015). In addition, it was also reported that APELA might

269 negatively regulate p53 in OCCC cell lines, causing non-apoptotic cell growth through an

270 APLNR-independent pathway (Yi et al., 2017). However, another study showed that increased

271 APLNR expression was significantly correlated with decreased median overall survival by 14.7

272 months in patients with high-grade serous ovarian cancer, and APLNR expression was both 
273 necessary and sufficient to increase prometastatic phenotypes of ovarian cancer cells including

274 the proliferation, cell adhesion, migration and invasion in vitro (Neelakantan et al., 2019).

275

276

\subsection{Distribution of APLN and APLNR in the oviduct}

277

The expression of apelinergic system in the ovary has been widely discussed. However, currently

278 only one study mentioned its expression in the sheep oviduct. This study showed that APLN was

279 detected in the epithelial cell coat of ampullary ciliated cells, which facilitated the transport of

280 oocytes and spermatozoa through the oviductal tract. APLNR was expressed exclusively in the ampullary secretory cells, suggesting the fertilization and implantation roles of this system

282 during the luteal stage (Mercati et al., 2019). In ewe oviduct, the mRNA level of both APLN and APLNR were detected higher in estrus when compared with those in anestrus. As the function of oviduct is to provide place for embryogenesis and transport of early embryo, the disruption of normal oviduct function may cause infertility, which is considering as a serious concern recently, and attracting more expected studies (Mercati et al., 2019).

\section{Role of APLN in uterus}

\subsection{Distribution and function of APLN and APLNR in uterus}

289 Recently, it has been witnessed that APLN and its receptor also display potential behaviors in uterus among species such as rat, mouse, ewe and human. The expression of APLNR mRNA in uterus was firstly detected through a nonspecific rat tissue RT-PCR screen (Hosoya et al., 2000), then its ligand APLN was described to be elevated during the secretory phase in the glandular cells of endometrial layer whereas it remained at a low level in the stromal cells (Kawamata et al., 2001; Ozkan et al., 2013; Mercati et al., 2019). It is evidently deduced that the apelinergic system is stimulated by elevated steroid hormones during the uterine secretory phase also known as the luteal phase of ovarian cycle. APLN subsequently plays a spatio-temporal role in spiral arterioles maturation and interstitial edema in endometrium where angiogenesis is taking place. An in vitro study showed that APLN played a vasodilation role in suppressing both spontaneous and oxytocin-induced contraction in human myometrial fibers (Hehir \& Morrison, 2012). However, serum APLN was also reported to exert a positive inotropic effect in rat myometrial layer via PKC-mediated intracellular $\mathrm{Ca}^{2+}$ amplication (Kacar et al., 2018). These opposite results may be explained by the intracellular balance between vascular dilation and smooth muscle contraction mechanisms of apelinergic system, as well as the impacts of species diversity and reagent concentrations.

305

\subsection{Role of APLN in endometriosis}

307 Endometriosis is defined as an estrogen-dependent invasion of endometrial tissue from uterus to uterine adnexa (Bulun et al., 2019). It is a very common cause for chronic pain in the pelvis and could even lead to infertility in moderate and significant patients (Chaljub, Medlock \& Services, 2018). Current explanations of endometriosis pathogenesis are endometrial implantation, 
311 coelomic metaplasia and induction theories which are all in agreement with the impacts of

312 steroid hormone dysregulation and inflammatory response. Similar expression pattern of APLN

313 was seen in both eutopic and ectopic endometrium during the menstrual cycle indicated that the

314 ectopic endometrial lesion could share some characteristics with eutopic cellular processes in

315 endometrium regeneration (Mercati et al., 2019). Additionally, the angiogenesis and vasodilation

316 effects of APLN could potentially be one of the causes in triggering the symptoms of

317 endometriosis, whereas more studies are expected to confirm this point.

318

319 7. Roles of APLN and APELA during pregnancy

3207.1 Role of APLN and APELA in embryonic development

321 APLNR was reported to be expressed in the angioblast of frog embryo, which would contribute

322 to the formation of aortic arch vessels and posterior cardinal veins. APLN was detected either

323 within or adjacent to the endothelial cells expressed by APLNR, functioning as an angiogenic

324 agent for nascent blood vessels, especially the intersegmental vessels formation. It also showed

325 the chemotactic ability of APLN to induce the migration of endothelial cells (Cox et al., 2006).

326 Moreover, APLN was proved possessing an anti-apoptotic role in osteoblastic cell line of

327 humans and mice (Tang et al., 2007; Xie et al., 2007). It releases Bcl-2 molecule from Bad via

328 activating PI3K/Akt pathway, which subsequently attenuates the activation of downstream

329 apoptotic factors, such as cytochrome $\mathrm{c}$ and caspase-3, resulting in the inhibition of osteoblastic

330 cell apoptosis.

331

332 Additionally, APELA has also been revealed to hold a key role in cardiogenesis, angiogenesis

333 and bone formation during the embryonic development. In APELA knockout mice, the hearts are

334 developed poorly or not developed at all, suggesting the essential role in heart morphogenesis

335 (Chng et al., 2013). It triggers the endothelial precursor (angioblasts) to migrate towards midline

336 and coalesce underneath the notochord, and form the first axial vessels (Pauli et al., 2014; Helker

337 et al., 2015). Consistently, APELA-APLNR axis is involved in early placental development and

338 angiogenesis (Ho et al., 2015, 2017). In mouse placenta, APELA is robustly expressed in

339 syncytiotrophoblasts from early-to-mid gestation, which favors the sprout of new formed blood

340 vessels (Ho et al., 2017). It is also associated with skeletal formation through inhibiting the

341 expression of Sox 32 , which can bind to Pou5f3 and Nanog molecules as a transcription factor in

342 dorsal endoderm during gastrulation, and inhibit the formation of Pou5f3-Nanog complex.

343 APELA-APLNR pathway can reduce Sox32 expression and allow Pou5f3-Nanog complexes

344 formation, subsequently activating bone morphogenetic protein signaling for sclerotome fate

345 determination (Perez-Camps et al., 2016).

346

347

348

\subsection{Distribution and function of APLN and APELA in the placenta}

Apelinergic system has been hypothesized as a key factor in placental angiogenesis. APLN was 
349 strongly expressed in the cytoplasm of human cytotrophoblasts during the first two trimester of

350 pregnancy, and then decreased at the third trimester. Subtle signals were also detected in the

351 syncytiotrophoblasts during the first trimester, but it disappeared completely in the third

352 trimester (Cobellis et al., 2007). The expression of APLNR in the placenta was later than that of

353 APLN. In the first trimester, it was relatively low and exclusively in the cytotrophoblasts.

354 However, in the third trimester, APLNR was expressed intensely not only in cytotrophoblasts but

355 also in syncytiotrophoblasts, smooth muscle cells and endothelial cells inside of the placental

356 villi (Cobellis et al., 2007). This change suggests a potential chemoarractant and vasculogenic

357 role of APLN in the invasion process of interstitial and endovascular extravillous trophoblasts. In

358 mouse, APELA was detected initially in the trophoblasts and then increased robustly after the

359 allantoic fusion. At the mid-gestation, it was expressed restrictedly in syncytiotrophoblasts,

360 where APLNR was wildly existed in adjacent endothelial cells, indicating a paracrine function of

361 this system to favor the placental angiogenic sprouting (Ho et al., 2017). However, in human

362 placenta, APELA was expressed in both cytotrophoblasts and syncytiotrophoblasts

363 synchronously during the whole pregnancy (Ho et al., 2017) and its speculated role remains to be

364 illuminated.

365

366

367

\subsection{Regulation of APELA and APLN in PE}

368

The basic pathological changes of hypertensive disorders in pregnancy are currently recognized

369

as insufficient spiral arteries recasting and inflammation mediated endothelial damage triggered

370 by the intricate network of signaling cascades. APELA as mentioned above plays a crucial role in placental angiogenesis via activating PI3K/AKT/mTOR pathway (Ho et al., 2017), and

371 whether its reduction could lead to PE is now being widely studied. It was firstly discovered that

372 APELA knockout pregnant mice exhibited a hypertensive symptom accompanied with

373 proteinuria and glomerular endotheliosis, which were manifested as preeclampsia-like symptoms

374 (Ho et al., 2017). Scientists therefore started investigating the change of APELA in PE patients

375 and wanted to know whether the APELA could act as a biomarker (Zhou et al., 2019). In the

376 late-onset PE (LOPE), two studies measured a significant increased concentration of APELA in

377 the placenta and serum (Panaitescu et al., 2020; Para et al., 2020), while one study measured significant decrease (Zhou et al., 2019). And for early-onset PE (EOPE), only one study observed decrease in both APELA mRNA and protein (Wang et al., 2019), while other studies report no significant change of APELA level on either protein or mRNA (Pritchard et al., 2018; Villie et al., 2019; Zhou et al., 2019; Panaitescu et al., 2020; Para et al., 2020). Furthermore, it was found that hypoxia significantly decreased the expression of LIN28B, LIN28A and APELA, and the downregulation of LIN28B and APELA may play a role in PE by reducing trophoblast invasion and syncytialization (Canfield et al., 2019).

385 
388 indicating a speculated correlation between APLN and PE (Cobellis et al., 2007). This study was

389 further proved by an experiment which showed intravenous injection of APLN in male mice

390 could lead to the downregulation of blood pressure, suggesting that APLN might act as a

391 vasodilator in PE (Lee et al., 2000). However, case studies also found either decreased (Inuzuka

392 et al., 2013; Yamaleyeva et al., 2015; Sattar Taha, Zahraei \& Al-Hakeim, 2020) or no

393 significantly changed (Van Mieghem et al., 2016) APLN level in PE patients compared with

394 normotensive pregnancies.

395

396

Not only its ligands, the expression of APLNR is also rather conflicting. It has long been thought that APLNR level increases when the patient suffer from PE (Cobellis et al., 2007), but two other studies suggest APLNR level remains unchanged when PE occurs (Yamaleyeva et al., 2015; Pritchard et al., 2018). However, one recent study found a significant decrease both in APLNR mRNA expression and in situ expression between PE patients and normal control, and this significance can be found when controls compared to both EOPE and LOPE groups (Zhou et al.,

402 2019).

403

Altogether, the different expression of apelinergic system could be explained by confounding factors like BMI and mean maternal age mismatches between the cases and controls. Moreover, the balance between vasorelaxant and myocardial contractile effects of apelinergic system, as well as the crosslink of apelinergic axis with intricate inflammatory and endothelial factors in PE should also be taken into consideration. Further investigations should focus on the specific molecular mechanisms of APLN and APELA in the hypertensive disorders of pregnancy.

\subsection{Regulation of APLN and APELA in GDM}

412 APLN as one of the adipose tissue-derived hormones has been identified to play a role in blood 413 glucose metabolism (Antushevich \& Wójcik, 2018). It has been described that insulin may up414 regulate the expression of APLN through PKC and PI3K signaling pathways in both murine and 415 human adipocytes (Boucher et al., 2005). Raised apelin levels were found in both insulin416 resistant mice and type 2 diabetes mellitus patients (Xu, Tsao \& Yue, 2011), which supported the 417 speculation that insulin can stimulate APLN secretion. Nevertheless, the correlation of APLN 418 levels with GDM has not yet reached an agreement in clinical researches. Three studies reported 419 a decrease of serum APLN level in GDM patients (Aydin, 2010; Boyadzhieva et al., 2013;

420 Akinci et al., 2014) while two other groups revealed an increase (Aslan et al., 2012; Caglayan et al., 2016). In contrast, there were also no significant association reports between normal control and GDM patients (Telejko et al., 2010; Oncul et al., 2013). Thus, the correlation of APLN with the pathophysiology of GDM remains to be elucidated. In addition, factors like BMI, HOMA-IR and birth weight have been shown not correlated with serum APLN level according to these studies (Aslan et al., 2012; Oncul et al., 2013), but these confounding factors varied a lot among 426 different groups during pregnancy, which was probably one of the cases in the controversy. 
427

428

429

430

431

432

433

434

435

436

437

438

439

440

441

442

443

444

445

446

447

448

449

450

451

452

453

454

455

456

457

458

459

460

461

\section{Additional information and Declarations}

Peer] reviewing PDF | (2020:05:48913:2:0:NEW 20 Sep 2020) monitoring and mechanism analysis (Guo et al., 2020).

\section{Conclusion} prophylactic intervention towards female reproductive disorders.

\section{Acknowledgments}

None.

APELA had a positive correlation with fasting plasma glucose levels in healthy pregnant women during the second trimester, while decreased APELA circulating level was observed in GDM patients at the same time. In the third trimester, circulating APELA level decreased significantly in both GDM and healthy groups. This study suggested that APELA could be a physiological demand in glucose metabolism, and further contributions should focus on dynamic levels

This review presents a landscape of the novel APLN/APELA-APLNR system in the female reproductive field (Table 1 and Fig 1 ). Intricate signaling pathways and crosslinks of APLN and APELA imply their multifunctional roles in different organs like ovary, uterus and placenta, during specific developmental stages. APLN as an adipokine appears to have specific effects in steriodogenesis and metabolic regulation in GCs and CL of the ovary. Insulin and IGF1-induced APLN secretion possibly plays a role in glucose regulation in GDM patients. In addition, APLN may sustain a balance between the vasodilative and myocontractile effects in the uterus which could be correlated with hypertensive disorders during the pregnancy. Similarly, APELA as a novel ligand of APLNR also has a potential role in PE, based on the angiogenic effect of spiral arterioles. APELA is essential for fetal and placental development through stimulating the invasion of extravillous trophoblasts. This process is potentially achieved through a chemoattractant mechanism in placental angiogenic sprouting. Moreover, there is a hyperplasia effect of APELA which could be one of the causes in ovarian tumorigenesis.

All the data suggest that there should be additional studies to further investigate the precise roles of this axis in female reproductive system especially at the pathological profile. In the future, it will be important to clarify the crosslink and interaction between APLN and other adipokines in sex hormone regulation and energy metabolism. Specific expression and biological effects of APELA in ovary and uterus are also needed in prospect. It may also be crucial to identify the balance of smooth muscle contraction and vasodilation in apelinergic system at a molecular hierarchy. Collectively, the apelinergic axis is still a novel project for further investigation in both physiological and pathological aspects, and probably brings better therapeutic or 


\section{Data availability}

464 All data supporting the conclusion of this article are included in this published article.

465

\section{List of Abbreviations}

467 AC: adenylate cyclase;

468 APELA: apelin receptor early endogenous ligand;

469 APLN: apelin;

470 APLNR: apelin receptor;

471 Bad: Bcl-2-associated death promoter;

472 BMI: body mass index;

$473 \mathrm{Ca}^{2+}$ : calcium;

474 cAMP: cyclic adenosine monophosphate;

475 CL: corpus luteum;

476 eNOS: endothelial nitric oxide synthase;

477 EOPE: early-onset preeclampsia

478 FSH: follicle stimulating hormone;

479 GDM: gestational diabetes mellitus;

480 GnRH: gonadotropin releasing hormone;

481 GPR25: G protein-coupled receptor 25;

482 GC: granulosa cell;

483 hESC: human embryonic stem cell;

484 hnRNPL: heterogeneous nuclear ribonucleoprotein L;

485 HOMA-IR: homeostatic model assessment for insulin resistance;

486 HPG axis: hypothalamo-pituitary-gonadal axis;

487 IGF: insulin-like growth factor;

488 LH: lutenizing hormone;

489 LOPE: late-onset preeclampsia

490 NO: nitric oxide;

491 OCCC: ovarian clear cell carcinoma;

492 PCOS: polycystic ovary syndrome;

493 PE: preeclampsia;

494 PI3K/Akt: phosphoinositide 3-kinase/protein kinase B;

495 PKA: protein kinase A;

496 PKC: protein kinase $\mathrm{C}$;

497 PLC- $\beta$ : phospholipase C- $\beta$;

498 ROS: reactive oxygen species.

499 
500

501

502

503

504

505

506

507

508

509

510

511

512

513

514

515

516

517

518

519

520

521

522

523

524

525

526

527

528

529

530

531

532

533

534

535

536

537

\section{Reference}

Akinci B, Celtik A, Tunali S, Genc S, Yuksel F, Secil M, Ozcan MA, Bayraktar F. 2014. Circulating apelin levels are associated with cardiometabolic risk factors in women with previous gestational diabetes. Archives of Gynecology and Obstetrics 289:787-793. DOI: 10.1007/s00404-013-3070-y.

Altinkaya SO, Nergiz S, Kucuk M, Yuksel H. 2014. Apelin levels in relation with hormonal and metabolic profile in patients with polycystic ovary syndrome. European Journal of Obstetrics and Gynecology and Reproductive Biology 176:168-172. DOI: 10.1016/j.ejogrb.2014.06.004.

Antushevich H, Wójcik M. 2018. Review: Apelin in disease. Clinica Chimica Acta 483:241248. DOI: 10.1016/j.cca.2018.05.012.

Aslan M, Celik O, Celik N, Turkcuoglu I, Yilmaz E, Karaer A, Simsek Y, Celik E, Aydin S. 2012. Cord blood nesfatin-1 and apelin-36 levels in gestational diabetes mellitus. Endocrine 41:424-429. DOI: 10.1007/s12020-011-9577-8.

Aydin S. 2010. The presence of the peptides apelin, ghrelin and nesfatin-1 in the human breast milk, and the lowering of their levels in patients with gestational diabetes mellitus. Peptides 31:2236-2240. DOI: 10.1016/j.peptides.2010.08.021.

Bertrand C, Valet P, Castan-Laurell I. 2015. Apelin and energy metabolism. Frontiers in Physiology 6:115. DOI: 10.3389/fphys.2015.00115.

Bongrani A, Mellouk N, Rame C, Cornuau M, Guérif F, Froment P, Dupont J. 2019. Ovarian expression of adipokines in polycystic ovary syndrome: A role for chemerin, omentin, and apelin in follicular growth arrest and ovulatory dysfunction? International Journal of Molecular Sciences 20:1-22. DOI: 10.3390/ijms20153778.

Boucher J, Masri B, Daviaud D, Gesta S, Guigné C, Mazzucotelli A, Castan-Laurell I, Tack I, Knibiehler B, Carpéné C, Audigier Y, Saulnier-Blache JS, Valet P. 2005. Apelin, a newly identified adipokine up-regulated by insulin and obesity. Endocrinology 146:1764-71. DOI: 10.1210/en.2004-1427.

Boyadzhieva M, Atanasova I, Zacharieva S, Kedikova S. 2013. Adipocytokines during pregnancy and postpartum in women with gestational diabetes and healthy controls. Journal of Endocrinological Investigation 36:944-949. DOI: 10.3275/8968.

Bulun SE, Yilmaz BD, Sison C, Miyazaki K, Bernardi L, Liu S, Kohlmeier A, Yin P, Milad M, Wei J. 2019. Endometriosis. Endocrine reviews 40:1048-1079. DOI: 10.1210/er.201800242.

Canfield J, Arlier S, Mong EF, Lockhart J, VanWye J, Guzeloglu-Kayisli O, Schatz F, Magness RR, Lockwood CJ, Tsibris JCM, Kayisli UA, Totary-Jain H. 2019. Decreased LIN28B in preeclampsia impairs human trophoblast differentiation and migration. FASEB journal 33:2759-2769. DOI: 10.1096/fj.201801163R.

Carpéné C, Dray C, Attané C, Valet P, Portillo MP, Churruca I, Milagro FI, Castan-Laurell I. 
538

539

540

541

542

543

544

545

546

547

548

549

550

551

552

553

554

555

556

557

558

559

560

561

562

563

564

565

566

567

568

569

570

571

572

573

574

575

576

2007. Expanding role for the apelin/APJ system in physiopathology. Journal of Physiology and Biochemistry 63:359-374. DOI: 10.1007/BF03165767.

Cekmez F, Cekmez Y, Pirgon Ö, Canpolat FE, Aydinöz S, Ipcioglu OM, Karademir F. 2011. Evaluation of new adipocytokines and insulin resistance in adolescents with polycystic ovary syndrome. European Cytokine Network 22:32-37. DOI: 10.1684/ecn.2011.0279.

Chapman NA, Dupré DJ, Rainey JK. 2014. The apelin receptor: Physiology, pathology, cell signalling, and ligand modulation of a peptide-activated class A GPCR. Biochemistry and Cell Biology 92:431-440. DOI: 10.1139/bcb-2014-0072.

Chng SC, Ho L, Tian J, Reversade B. 2013. ELABELA: A hormone essential for heart development signals via the apelin receptor. Developmental Cell 27:672-680. DOI: 10.1016/j.devcel.2013.11.002.

Cho HJ, Acharjee S, Moon MJ, Oh DY, Vaudry H, Kwon HB, Seong JY. 2007. Molecular evolution of neuropeptide receptors with regard to maintaining high affinity to their authentic ligands. General and Comparative Endocrinology 153:98-107. DOI: 10.1016/j.ygcen.2006.12.013.

Cobellis L, De Falco M, Mastrogiacomo A, Giraldi D, Dattilo D, Scaffa C, Colacurci N, De Luca A. 2007. Modulation of apelin and APJ receptor in normal and preeclampsiacomplicated placentas. Histology and Histopathology 22:1-8. DOI: 10.14670/HH-22.1.

Cox CM, D’Agostino SL, Miller MK, Heimark RL, Krieg PA. 2006. Apelin, the ligand for the endothelial G-protein-coupled receptor, APJ, is a potent angiogenic factor required for normal vascular development of the frog embryo. Developmental Biology 296:177-189. DOI: 10.1016/j.ydbio.2006.04.452.

Dai T, Ramirez-Correa G, Gao WD. 2006. Apelin increases contractility in failing cardiac muscle. European Journal of Pharmacology 553:222. DOI: 10.1016/j.ejphar.2006.09.034.

Fagerberg L, Hallstrom BM, Oksvold P, Kampf C, Djureinovic D, Odeberg J, Habuka M, Tahmasebpoor S, Danielsson A, Edlund K, Asplund A, Sjostedt E, Lundberg E, Szigyarto CAK, Skogs M, Ottosson Takanen J, Berling H, Tegel H, Mulder J, Nilsson P, Schwenk JM, Lindskog C, Danielsson F, Mardinoglu A, Sivertsson A, Von Feilitzen K, Forsberg M, Zwahlen M, Olsson I, Navani S, Huss M, Nielsen J, Ponten F, Uhlen M. 2014. Analysis of the human tissue-specific expression by genome-wide integration of transcriptomics and antibody-based proteomics. Molecular and Cellular Proteomics 13:397-406. DOI: 10.1074/mcp.M113.035600.

Farrell K, Antoni MH. 2010. Insulin resistance, obesity, inflammation, and depression in polycystic ovary syndrome: Biobehavioral mechanisms and interventions. Fertility and Sterility 94:1565-74. DOI: 10.1016/j.fertnstert.2010.03.081.

Guo YY, Li T, Liu H, Tang L, Li YC, Hu HT, Su YF, Lin Y, Wang YY, Li C, Huang HF, Jin L, Liu XM. 2020. Circulating levels of Elabela and Apelin in the second and third trimesters of pregnancies with gestational diabetes mellitus. Gynecological Endocrinology 3590. DOI: 10.1080/09513590.2020.1739264. 
577

578

579

580

581

582

583

584

585

586

587

588

589

590

591

592

593

594

595

596

597

598

601

602

603

604

605

606

607

608

609

610

611

612

613

614

615

Hehir MP, Morrison JJ. 2012. The adipokine apelin and human uterine contractility. American Journal of Obstetrics and Gynecology 206:359.e1-359.e5. DOI:

10.1016/j.ajog.2012.01.032.

Helker CSM, Schuermann A, Pollmann C, Chng SC, Kiefer F, Reversade B, Herzog W. 2015. The hormonal peptide Elabela guides angiob lasts to the midline during vasculogenesis. eLife 4:1-13. DOI: 10.7554/eLife.06726.

Ho L, Dijk M Van, Tan S, Chye J, Messerschmidt DM, Chng SC, Ong S, Yi LK, Boussata S, Goh GH, Afink GB, Lim CY, Dunn NR, Solter D, Knowles BB, Reversade B. 2017. ELABELA deficiency promotes preeclampsia and cardiovascular malformations in mice. Science 357:707-713. DOI: 10.1126/science.aam6607.

Ho L, Tan SJCSYX, Wee S, Wu Y, Tan SJCSYX, Ramakrishna NB, Chng SC, Nama S, Szczerbinska I, Chan YS, Avery S, Tsuneyoshi N, Ng HH, Gunaratne J, Dunn NR, Reversade B. 2015. ELABELA Is an Endogenous Growth Factor that Sustains hESC SelfRenewal via the PI3K/AKT Pathway. Cell Stem Cell 17:435-447. DOI: 10.1016/j.stem.2015.08.010.

Hoffmann M, Fiedor E, Ptak A. 2017. Bisphenol A and its derivatives tetrabromobisphenol A and tetrachlorobisphenol A induce apelin expression and secretion in ovarian cancer cells through a peroxisome proliferator-activated receptor gamma-dependent mechanism. Toxicology Letters 269:15-22. DOI: 10.1016/j.toxlet.2017.01.006.

Hosoya M, Kawamata Y, Fukusumi S, Fujii R, Habata Y, Hinumat S, Kitada C, Honda S, Kurokawa T, Onda H, Nishimura O, Fujino M. 2000. Molecular and functional characteristics of APJ: Tissue distribution of mRNA and interaction with the endogenous ligand apelin. Journal of Biological Chemistry 275:21061-21067. DOI: 10.1074/jbc.M908417199.

Huang SK, Shin K, Sarker M, Rainey JK. 2017. Apela exhibits isoform- and headgroupdependent modulation of micelle binding, peptide conformation and dynamics. Biochimica et Biophysica Acta - Biomembranes 1859:767-778. DOI: 10.1016/j.bbamem.2017.01.028.

Inuzuka H, Nishizawa H, Inagaki A, Suzuki M, Ota S, Miyamura H, Miyazaki J, Sekiya T, Kurahashi H, Udagawa Y. 2013. Decreased expression of apelin in placentas from severe pre-eclampsia patients. Hypertension in Pregnancy 32:410. DOI:

10.3109/10641955.2013.813535.

Jin JM, Yang WX. 2014. Molecular regulation of hypothalamus-pituitary-gonads axis in males. Gene 551:15-25. DOI: 10.1016/j.gene.2014.08.048.

Kacar E, Ercan Z, Serhatlioglu I, Sumer A, Kelestimur H, Kutlu S. 2018. The effects of apelin on myometrium contractions in pregnant rats. Cellular and Molecular Biology 64:74-79. DOI: 10.14715/cmb/2018.64.11.13.

Kasai A, Shintani N, Kato H, Matsuda S, Gomi F, Haba R, Hashimoto H, Kakuda M, Tano Y, Baba A. 2008. Retardation of retinal vascular development in apelin-deficient mice. Arteriosclerosis, Thrombosis, and Vascular Biology 28:1717-1722. DOI: 
616

617

618

619

620

621

622

623

624

625

626

627

628

629

630

631

632

633

634

635

636

637

638

639

640

641

642

643

644

645

646

647

648

649

650

651

652

653

654

10.1161/ATVBAHA.108.163402.

Kawamata Y, Habata Y, Fukusumi S, Hosoya M, Fujii R, Hinuma S, Nishizawa N, Kitada C, Onda H, Nishimura O, Fujino M. 2001. Molecular properties of apelin: Tissue distribution and receptor binding. Biochimica et Biophysica Acta-Molecular Cell Research 1538:162171. DOI: 10.1016/S0167-4889(00)00143-9.

Kiyak Caglayan E, Engin-Ustun Y, Sari N, Gocmen AY, Polat MF. 2016. The effects of prolonged fasting on the levels of adiponectin, leptin, apelin, and omentin in pregnant women. Journal of Obstetrics and Gynaecology 36:555-558. DOI: 10.3109/01443615.2015.1103716.

Krist J, Wieder K, Klöting N, Oberbach A, Kralisch S, Wiesner T, Schön MR, Gärtner D, Dietrich A, Shang E, Lohmann T, Dreßler M, Fasshauer M, Stumvoll M, Blüher M. 2013. Effects of weight loss and exercise on apelin serum concentrations and adipose tissue expression in human obesity. Obesity Facts 6:57-69. DOI: 10.1159/000348667.

Lee DL, Cheng R, Nguyen T, Fan T, Kariyawasam AP, Liu Y, Osmond DH, George SR, O'Dowd BF. 2000. Characterization of apelin, the ligand for the APJ receptor. Journal of Neurochemistry 74:34-41. DOI: 10.1046/j.1471-4159.2000.0740034.x.

Li M, Gou H, Tripathi BK, Huang J, Jiang S, Dubois W, Waybright T, Lei M, Shi J, Zhou M. 2015. An Apela RNA-Containing Negative Feedback Loop Regulates p53-Mediated Apoptosis in Embryonic Stem Cells. Cell Stem Cell 16:669-683. DOI: 10.1016/j.stem.2015.04.002.

Liu C, Su T, Li F, Li L, Qin X, Pan W, Feng F, Chen F, Liao D, Chen L. 2010. PI3K/Akt signaling transduction pathway is involved in rat vascular smooth muscle cell proliferation induced by apelin-13. Acta Biochimica et Biophysica Sinica 42:396-402. DOI: 10.1093/abbs/gmq035.

Liu Y, Zhang T, Wang Y, Wu P, Li Y, Wang C, Xu S, Shi H. 2019. Apelin-13 attenuates early brain injury following subarachnoid hemorrhage via suppressing neuronal apoptosis through the GLP-1R/PI3K/Akt signaling. Biochemical and Biophysical Research Communications 513:105-111. DOI: 10.1016/j.bbrc.2019.03.151.

Lv SY, Cui B, Chen WD, Wang YD. 2017. Apelin/APJ system: A key therapeutic target for liver disease. Oncotarget 8:112145-112151. DOI: 10.18632/oncotarget.22841.

Maguire JJ, Kleinz MJ, Pitkin SL, Davenport AP. 2009. [Pyr1] apelin-13 identified as the predominant apelin isoform in the human heart: Vasoactive mechanisms and inotropic action in disease. Hypertension 54:598-604. DOI: 10.1161/HYPERTENSIONAHA.109.134619.

Masoumi J, Jafarzadeh A, Khorramdelazad H, Abbasloui M, Abdolalizadeh J, Jamali N. 2020. Role of Apelin/APJ axis in cancer development and progression. Advances in Medical Sciences 65:202-213. DOI: 10.1016/j.advms.2020.02.002.

Masri B, Knibiehler B, Audigier Y, Lahlou H, Mazarguil H. 2002. Apelin (65-77) activates extracellular signal-regulated kinases via a PTX-sensitive G protein. Biochemical and 
655

656

657

658

659

660

661

662

663

664

665

666

667

668

669

670

671

672

673

674

675

676

677

678

679

680

681

682

683

684

685

686

687

688

689

690

691

692

693

Biophysical Research Communications 290:539-545. DOI: 10.1006/bbrc.2001.6230.

Mercati F, Scocco P, Maranesi M, Acuti G, Petrucci L, Cocci P, Renzi A, De Felice E, Dall'Aglio C. 2019. Apelin system detection in the reproductive apparatus of ewes grazing on semi-natural pasture. Theriogenology 139:156-166. DOI:

10.1016/j.theriogenology.2019.08.012.

El Messari S, Iturrioz X, Fassot C, De Mota N, Roesch D, Llorens-Cortes C. 2004. Functional dissociation of apelin receptor signaling and endocytosis: Implications for the effects of apelin on arterial blood pressure. Journal of Neurochemistry 90:1290-1301. DOI: 10.1111/j.1471-4159.2004.02591.x.

Van Mieghem T, Doherty A, Baczyk D, Drewlo S, Baud D, Carvalho J, Kingdom J. 2016. Apelin in Normal Pregnancy and Pregnancies Complicated by Placental Insufficiency. Reproductive Sciences 23:1037-1043. DOI: 10.1177/1933719116630422.

Neelakantan D, Dogra S, Devapatla B, Jaiprasart P, Mukashyaka MC, Janknecht R, Dwivedi SKD, Bhattacharya R, Husain S, Ding K, Woo S. 2019. Multifunctional APJ pathway promotes ovarian cancer progression and metastasis. Molecular cancer research 17:13781390. DOI: 10.1158/1541-7786.MCR-18-0989.

Norris ML, Pauli A, Gagnon JA, Lord ND, Rogers KW, Mosimann C, Zon LI, Schier AF. 2017. Toddler signaling regulates mesodermal cell migration downstream of nodal signaling. eLife 6:1-18. DOI: 10.7554/eLife.22626.

O’Dowd BF, Heiber M, Chan A, Heng HHQ, Tsui LC, Kennedy JL, Shi X, Petronis A, George SR, Nguyen T. 1993. A human gene that shows identity with the gene encoding the angiotensin receptor is located on chromosome 11. Gene 136:355-360. DOI: 10.1016/03781119(93)90495-O.

Olszanecka-Glinianowicz M, Madej P, Owczarek A, Chudek J, Skałba P. 2015. Circulating antiMüllerian hormone levels in relation to nutritional status and selected adipokines levels in polycystic ovary syndrome. Clinical Endocrinology 83:98-104. DOI: 10.1111/cen.12687.

Oncul M, Tuten A, Erman H, Gelisgen R, Benian A, Uzun H. 2013. Maternal and cord blood apelin, resistin and visfatin levels in gestational diabetes mellitus. Minerva Medica 104:527. DOI: 10.1186/1471-2296-14-145.

Ozkan ZS, Cilgin H, Simsek M, Cobanoglu B, Ilhan N. 2013. Investigation of apelin expression in endometriosis. Journal of Reproduction and Infertility 14:50-55.

Panaitescu B, Romero R, Gomez-Lopez N, Pacora P, Erez O, Vadillo-Ortega F, Yeo L, Hassan SS, Hsu CD. 2020. ELABELA plasma concentrations are increased in women with lateonset preeclampsia. Journal of Maternal-Fetal and Neonatal Medicine 33:5-15. DOI: 10.1080/14767058.2018.1484089.

Para R, Romero R, Gomez-Lopez N, Tarca AL, Panaitescu B, Done B, Hsu R, Pacora P, Hsu CD. 2020. Maternal circulating concentrations of soluble Fas and Elabela in early- and lateonset preeclampsia. Journal of Maternal-Fetal and Neonatal Medicine 0:1-14. DOI: 10.1080/14767058.2020.1716720.

Peer] reviewing PDF | (2020:05:48913:2:0:NEW 20 Sep 2020) 
694 Pauli A, Norris ML, Valen E, Chew GL, Gagnon JA, Zimmerman S, Mitchell A, Ma J, Dubrulle

695 J, Reyon D, Tsai SQ, Joung JK, Saghatelian A, Schier AF. 2014. Toddler: An embryonic

696 signal that promotes cell movement via apelin receptors. Science 343:1248636. DOI:

$697 \quad 10.1126 /$ science. 1248636.

698 Peiris A, Chaljub E, Medlock D. 2018. Endometriosis. JAMA: The Journal of the American

699 Medical Association 320:2608. DOI: 10.1001/jama.2018.17953.

700 Peng X, Li F, Wang P, Jia S, Sun L, Huo H. 2015. Apelin-13 induces MCF-7 cell proliferation

701 and invasion via phosphorylation of ERK1/2. International Journal of Molecular Medicine

702 36:733-738. DOI: 10.3892/ijmm.2015.2265.

703 Perez-Camps M, Tian J, Chng SC, Sem KP, Sudhaharan T, Teh C, Wachsmuth M, Korzh V,

704

705

706

707

708

709

710

711

712

713

714

715

716

717

718

719

720

721

722

723

724

725

726

727

728

729

730

731

732 Ahmed S, Reversade B. 2016. Quantitative imaging reveals real-time Pou5f3-nanog complexes driving dorsoventral mesendoderm patterning in zebrafish. eLife 5:1-21. DOI: 10.7554/eLife. 11475.

Perjés Á, Kilpiö T, Ulvila J, Magga J, Alakoski T, Szabó Z, Vainio L, Halmetoja E, Vuolteenaho O, Petäjä-Repo U, Szokodi I, Kerkelä R. 2016. Characterization of apela, a novel endogenous ligand of apelin receptor, in the adult heart. Basic Research in Cardiology 111:1-12. DOI: 10.1007/s00395-015-0521-6.

Pope GR, Roberts EM, Lolait SJ, O\&apos;Carroll AM. 2012. Central and peripheral apelin receptor distribution in the mouse: Species differences with rat. Peptides 33:139-148. DOI: 10.1016/j.peptides.2011.12.005.

Pritchard N, Kaitu'u-Lino TJ, Gong S, Dopierala J, Smith GCS, Charnock-Jones DS, Tong S. 2018. ELABELA/APELA Levels Are Not Decreased in the Maternal Circulation or Placenta among Women with Preeclampsia. American Journal of Pathology 188:17491753. DOI: 10.1016/j.ajpath.2018.04.008.

Qian J, Lu Q, Tao Y, Jiang YR. 2011. Vitreous and plasma concentrations of apelin and vascular endothelial growth factor after intravitreal bevacizumab in eyes with proliferative diabetic retinopathy. Retina 31:161-168. DOI: 10.1097/IAE.0b013e3181e46ad8.

Rak A, Drwal E, Rame C, Knapczyk-Stwora K, Słomczyńska M, Dupont J, Gregoraszczuk EL. 2017. Expression of apelin and apelin receptor (APJ) in porcine ovarian follicles and in vitro effect of apelin on steroidogenesis and proliferation through APJ activation and different signaling pathways. Theriogenology 96:126-135. DOI: 10.1016/j.theriogenology.2017.04.014.

Roche J, Rame C, Reverchon M, Mellouk N, Cornuau M, Guerif F, Froment P, Dupont J. 2016. Apelin (APLN) and Apelin Receptor (APLNR) in Human Ovary: Expression, Signaling, and Regulation of Steroidogenesis in Primary Human Luteinized Granulosa Cells. Biology of Reproduction 95:104-104. DOI: 10.1095/biolreprod.116.141754.

Roche J, Ramé C, Reverchon M, Mellouk N, Rak A, Froment P, Dupont J. 2017. Apelin (APLN) regulates progesterone secretion and oocyte maturation in bovine ovarian cells. Reproduction 153:589-603. DOI: 10.1530/REP-16-0677. 
733

734

735

736

737

738

739

740

741

742

743

744

745

746

747

748

749

750

751

752

753

754

755

756

757

758

759

760

761

762

763

764

765

766

767

768

769

770

771

Różycka M, Kurowska P, Grzesiak M, Kotula-Balak M, Tworzydło W, Rame C, Gregoraszczuk E, Dupont J, Rak A. 2018. Apelin and apelin receptor at different stages of corpus luteum development and effect of apelin on progesterone secretion and 3 $\beta$-hydroxysteroid dehydrogenase (3ß-HSD) in pigs. Animal Reproduction Science 192:251-260. DOI: 10.1016/j.anireprosci.2018.03.021.

Santoso P, Maejima Y, Kumamoto K, Takenoshita S, Shimomura K. 2015. Central action of ELABELA reduces food intake and activates arginine vasopressin and corticotropinreleasing hormone neurons in the hypothalamic paraventricular nucleus. NeuroReport 26:820-826. DOI: 10.1097/WNR.0000000000000431.

Sattar Taha A, Zahraei Z, Al-Hakeim HK. 2020. Serum apelin and galectin-3 in preeclampsia in Iraq. Hypertension in Pregnancy 00:1-8. DOI: 10.1080/10641955.2020.1777300.

Schilffarth S, Antoni B, Schams D, Meyer HHD, Berisha B. 2009. The expression of apelin and its receptor APJ during different physiological stages in the bovine ovary. International Journal of Biological Sciences 5:344-350. DOI: 10.7150/ijbs.5.344.

Shimizu T, Kosaka N, Murayama C, Tetsuka M, Miyamoto A. 2009. Apelin and APJ receptor expression in granulosa and theca cells during different stages of follicular development in the bovine ovary: Involvement of apoptosis and hormonal regulation. Animal Reproduction Science 116:28-37. DOI: 10.1016/j.anireprosci.2009.01.009.

Shirasuna K, Shimizu T, Sayama K, Asahi T, Sasaki M, Berisha B, Schams D, Miyamoto A. 2008. Expression and localization of apelin and its receptor APJ in the bovine corpus luteum during the estrous cycle and prostaglandin F2 $\alpha$-induced luteolysis. Reproduction 135:519-525. DOI: 10.1530/REP-07-0409.

Shuang L, Jidong W, Hongjuan P, Zhenwei Y. 2016. Effects of apelin on proliferation and apoptosis in rat ovarian granulosa cells. Clinical and Experimental Obstetrics and Gynecology 43:409. DOI: 10.12891/ $\operatorname{ceog} 2133.2016$.

Sun X, Wu X, Zhou Y, Yu X, Zhang W. 2015. Evaluation of apelin and insulin resistance in patients with PCOS and therapeutic effect of drospirenone-ethinylestradiol plus metformin. Medical Science Monitor 21:2547-2552. DOI: 10.12659/MSM.894926.

Szokodi I, Tavi P, Földes G, Voutilainen-Myllylä S, Ilves M, Tokola H, Pikkarainen S, Piuhola J, Rysä J, Tóth M, Ruskoaho H. 2002. Apelin, the novel endogenous ligand of the orphan receptor APJ, regulates cardiac contractility. Circulation Research 91:434-440. DOI: 10.1161/01.RES.0000033522.37861.69.

Taheri S, Murphy K, Cohen M, Sujkovic E, Kennedy A, Dhillo W, Dakin C, Sajedi A, Ghatei M, Bloom S. 2002. The effects of centrally administered apelin-13 on food intake, water intake and pituitary hormone release in rats. Biochemical and Biophysical Research

Communications 291:1208-1212. DOI: 10.1006/bbrc.2002.6575.

Tang SY, Xie H, Yuan LQ, Luo XH, Huang J, Cui RR, Zhou H De, Wu XP, Liao EY. 2007. Apelin stimulates proliferation and suppresses apoptosis of mouse osteoblastic cell line MC3T3-E1 via JNK and PI3-K/Akt signaling pathways. Peptides 28:708-718. DOI: 
772

773

774

775

776

777

778

779

780

781

782

783

784

785

786

787

788

789

790

791

792

793

794

795

796

797

798

799

800

801

802

803

804

805

806

807

808

809

810

10.1016/j.peptides.2006.10.005.

Tatemoto K, Hosoya M, Habata Y, Fujii R, Kakegawa T, Zou MX, Kawamata Y, Fukusumi S, Hinuma S, Kitada C, Kurokawa T, Onda H, Fujino M. 1998. Isolation and characterization of a novel endogenous peptide ligand for the human APJ receptor. Biochemical and Biophysical Research Communications 251:471-476. DOI: 10.1006/bbrc.1998.9489.

Teede H, Deeks A, Moran L. 2010. Polycystic ovary syndrome: A complex condition with psychological, reproductive and metabolic manifestations that impacts on health across the lifespan. BMC Medicine 8:1-10. DOI: 10.1186/1741-7015-8-41.

Teede HJ, Misso ML, Costello MF, Dokras A, Laven J, Moran L, Cert Pub Health G, Piltonen T, Norman RJ. 2018. Recommendations from the international evidence-based guideline for the assessment and management of polycystic ovary syndrome on behalf of the International PCOS. Fertility and Sterility 110:364-79. DOI:

10.1016/j.fertnstert.2018.05.004.

Tekin S, Erden Y, Sandal S, Etem Onalan E, Ozyalin F, Ozen H, Yilmaz B. 2017. Effects of apelin on reproductive functions: relationship with feeding behavior and energy metabolism. Archives of Physiology and Biochemistry 123:9-15. DOI: 10.1080/13813455.2016.1211709.

Telejko B, Kuzmicki M, Wawrusiewicz-Kurylonek N, Szamatowicz J, Nikolajuk A, Zonenberg A, Zwierz-Gugala D, Jelski W, Laudański P, Wilczynski J, Kretowski A, Gorska M. 2010. Plasma apelin levels and apelin/APJ mRNA expression in patients with gestational diabetes mellitus. Diabetes Research and Clinical Practice 87:176-183. DOI: 10.1016/j.diabres.2009.10.018.

Than A, Zhang X, Leow MKS, Poh CL, Chong SK, Chen P. 2014. Apelin attenuates Oxidative stress in human Adipocytes. Journal of Biological Chemistry 289:3763-3774. DOI: 10.1074/jbc.M113.526210.

Ulitsky I, Shkumatava A, Jan CH, Sive H, Bartel DP. 2011. Conserved function of lincRNAs in vertebrate embryonic development despite rapid sequence evolution. Cell 147:1537-1550. DOI: 10.1016/j.cell.2011.11.055.

Villie P, Lefevre G, Arrestier R, Rousseau A, Berkane N, Hertig A. 2019. ELABELA concentration is not decreased in maternal plasma before the onset of preeclampsia. American Journal of Obstetrics and Gynecology 220:284-285. DOI: 10.1016/j.ajog.2018.12.020.

Wang Z, Yu D, Wang M, Wang Q, Kouznetsova J, Yang R, Qian K, Wu W, Shuldiner A, Sztalryd C, Zou M, Zheng W, Gong DW. 2015. Elabela-Apelin Receptor Signaling Pathway is Functional in Mammalian Systems. Scientific Reports 5:1-8. DOI: 10.1038/srep08170.

Wang L, Zhang Y, Qu H, Xu F, Hu H, Zhang Q, Ye Y. 2019. Reduced ELABELA expression attenuates trophoblast invasion through the PI3K/AKT/mTOR pathway in early onset preeclampsia. Placenta 87:38-45. DOI: 10.1016/j.placenta.2019.08.077.

Peer] reviewing PDF | (2020:05:48913:2:0:NEW 20 Sep 2020) 
811 Wyskida K, Franik G, Wikarek T, Owczarek A, Delroba A, Chudek J, Sikora J, Olszanecka-

812 Glinianowicz M. 2017. The levels of adipokines in relation to hormonal changes during the 813 menstrual cycle in young, normal-weight women. Endocrine Connections 6:892-900. DOI: $814 \quad 10.1530 /$ EC-17-0186.

815 Xie H, Yuan LQ, Luo XH, Huang J, Cui RR, Guo LJ, Zhou H De, Wu XP, Liao EY. 2007.

816 Apelin suppresses apoptosis of human osteoblasts. Apoptosis 12:247-254. DOI:

$817 \quad 10.1007 / \mathrm{s} 10495-006-0489-7$.

818 Xu S, Tsao PS, Yue P. 2011. Apelin and insulin resistance: Another arrow for the quiver?

819 Journal of Diabetes 3:225-231. DOI: 10.1111/j.1753-0407.2011.00132.x.

820 Yamaleyeva LM, Chappell MC, Bridget Brosnihan K, Anton L, Caudell DL, Shi S, McGee C,

821 Pirro N, Gallagher PE, Taylor RN, Merrill DC, Mertz HL. 2015. Downregulation of apelin

822 in the human placental chorionic villi from preeclamptic pregnancies. American Journal of

823

824

825

826

827

828

829

830

831

832

833

834

835

836

837

838

839

840

841

842

843

844

845

846

847

848

849 Physiology - Endocrinology and Metabolism 309:852-860. DOI: 10.1152/ajpendo.00272.2015.

Yang N, Li T, Cheng J, Tuo Q, Shen J. 2019. Role of apelin/APJ system in hypothalamicpituitary axis. Clinica Chimica Acta 499:149-153. DOI: 10.1016/j.cca.2019.09.011.

Yang X, Zhu W, Zhang P, Chen K, Zhao L, Li J, Wei M, Liu M. 2014. Apelin-13 stimulates angiogenesis by promoting cross-talk between AMP-activated protein kinase and Akt signaling in myocardial microvascular endothelial cells. Molecular Medicine Reports 9:1590-1596. DOI: 10.3892/mmr.2014.1984.

Yi Y, Tsai SH, Cheng JC, Wang EY, Anglesio MS, Cochrane DR, Fuller M, Gibb EA, Wei W, Huntsman DG, Karsan A, Hoodless PA. 2017. APELA promotes tumour growth and cell migration in ovarian cancer in a p53-dependent manner. Gynecologic Oncology 147:663671. DOI: 10.1016/j.ygyno.2017.10.016.

Yue F, Cheng Y, Breschi A, Vierstra J, Wu W, Ryba T, Sandstrom R, Ma Z, Davis C, Pope BD, Shen Y, Pervouchine DD, Djebali S, Thurman RE, Kaul R, Rynes E, Kirilusha A, Marinov GK, Williams BA, Trout D, Amrhein H, Fisher-Aylor K, Antoshechkin I, DeSalvo G, See LH, Fastuca M, Drenkow J, Zaleski C, Dobin A, Prieto P, Lagarde J, Bussotti G, Tanzer A, Denas O, Li K, Bender MA, Zhang M, Byron R, Groudine MT, McCleary D, Pham L, Ye Z, Kuan S, Edsall L, Wu YC, Rasmussen MD, Bansal MS, Kellis M, Keller CA, Morrissey CS, Mishra T, Jain D, Dogan N, Harris RS, Cayting P, Kawli T, Boyle AP, Euskirchen G, Kundaje A, Lin S, Lin Y, Jansen C, Malladi VS, Cline MS, Erickson DT, Kirkup VM, Learned K, Sloan CA, Rosenbloom KR, De Sousa BL, Beal K, Pignatelli M, Flicek P, Lian J, Kahveci T, Lee D, Kent WJ, Santos MR, Herrero J, Notredame C, Johnson A, Vong S, Lee K, Bates D, Neri F, Diegel M, Canfield T, Sabo PJ, Wilken MS, Reh TA, Giste E, Shafer A, Kutyavin T, Haugen E, Dunn D, Reynolds AP, Neph S, Humbert R, Hansen RS, De Bruijn M, Selleri L, Rudensky A, Josefowicz S, Samstein R, Eichler EE, Orkin SH, Levasseur D, Papayannopoulou T, Chang KH, Skoultchi A, Gosh S, Disteche C, Treuting P, Wang Y, Weiss MJ, Blobel GA, Cao X, Zhong S, Wang T, Good PJ, Lowdon RF, Adams 
850

851

852

853

854

855

856

857

858

859

860

861

862

863

864

865

866

867

868

869

870

871

872

873

874

875

876

877

878

879

880

881

882

883

884

LB, Zhou XQ, Pazin MJ, Feingold EA, Wold B, Taylor J, Mortazavi A, Weissman SM, Stamatoyannopoulos JA, Snyder MP, Guigo R, Gingeras TR, Gilbert DM, Hardison RC, Beer MA, Ren B. 2014. A comparative encyclopedia of DNA elements in the mouse genome. Nature 515:355-364. DOI: 10.1038/nature13992.

Zeng XXI, Wilm TP, Sepich DS, Solnica-Krezel L. 2007. Apelin and Its Receptor Control Heart Field Formation during Zebrafish Gastrulation. Developmental Cell 12:391-402. DOI: 10.1016/j.devcel.2007.01.011.

Zhang J, Wan Y, Fang C, Chen J, Ouyang W, Li J, Wang Y. 2018. The orphan G proteincoupled receptor 25 (GPR25) is activated by Apelin and Apela in non-mammalian vertebrates. Biochemical and Biophysical Research Communications 501:408-414. DOI: 10.1016/j.bbrc.2018.04.229.

Zhou L, Sun H, Cheng R, Fan X, Lai XS, Deng C. 2019. ELABELA, as a potential diagnostic biomarker of preeclampsia, regulates abnormally shallow placentation via APJ. American Journal of Physiology - Endocrinology and Metabolism 316:E773-E781. DOI: 10.1152/ajpendo.00383.2018.

\section{Figure legends}

Figure 1: Expression and function of APLN and APELA in reproduction system.

(A) In physiological conditions, APLN (in blue textbox) and APELA (in green textbox) play diverse roles at the different parts of the ovary, uterus and placenta. (B) In pathological conditions, aberrant expression of APLN (in orange textbox) and APELA (in purple textbox) lead to female reproductive disorders such as polycystic ovary syndrome (PCOS), ovarian cancer, preeclampsia (PE), gestational diabetes mellitus (GDM) and endometriosis. * indicating potential apelinergic stimulating factors. ? indicating still unclear or controversy about the functions or contributions of apelinergic molecules in these diseases. $\uparrow$ and $\downarrow$ in the textbox means increase and decrease respectively, both indicate statistically significant changes. $\rightarrow$ means resulting.

Figure 2: Intracellular signaling pathways and physiological functions of APLN and APELA.

(A) Both APLN (in blue) and APELA (in orange) can classically activate Gai/o and Gaq/11 mediated intracellular transduction via binding to their common receptor APLNR. (B) Noncoding APELA binds to hnRNPL and promotes p53-mediated cell apoptosis. (C) APELA also stimulates PI3K-independent NODAL/TGF $\beta$ signal through alternative receptors in hESCs. AC, adenylate cyclase; eNOS, endothelial nitric oxide synthase; IncRNA, long non-coding RNA; hnRNPL, heterogeneous nuclear ribonucleoprotein L. 
Figure 1

Expression and function of APLN and APELA in reproduction system.

(A) In physiological conditions, APLN (in blue textbox) and APELA (in green textbox) play diverse roles at the different parts of the ovary, uterus and placenta. (B) In pathological conditions, aberrant expression of APLN (in orange textbox) and APELA (in purple textbox) lead to female reproductive disorders such as polycystic ovary syndrome (PCOS), ovarian cancer, preeclampsia (PE), gestational diabetes mellitus (GDM) and endometriosis. * indicating potential apelinergic stimulating factors. ? indicating still unclear or controversy about the functions or contributions of apelinergic molecules in these diseases. $\uparrow$ and $\downarrow$ in the textbox means increase and decrease respectively, both indicate statistically significant changes. $\rightarrow$ means resulting.

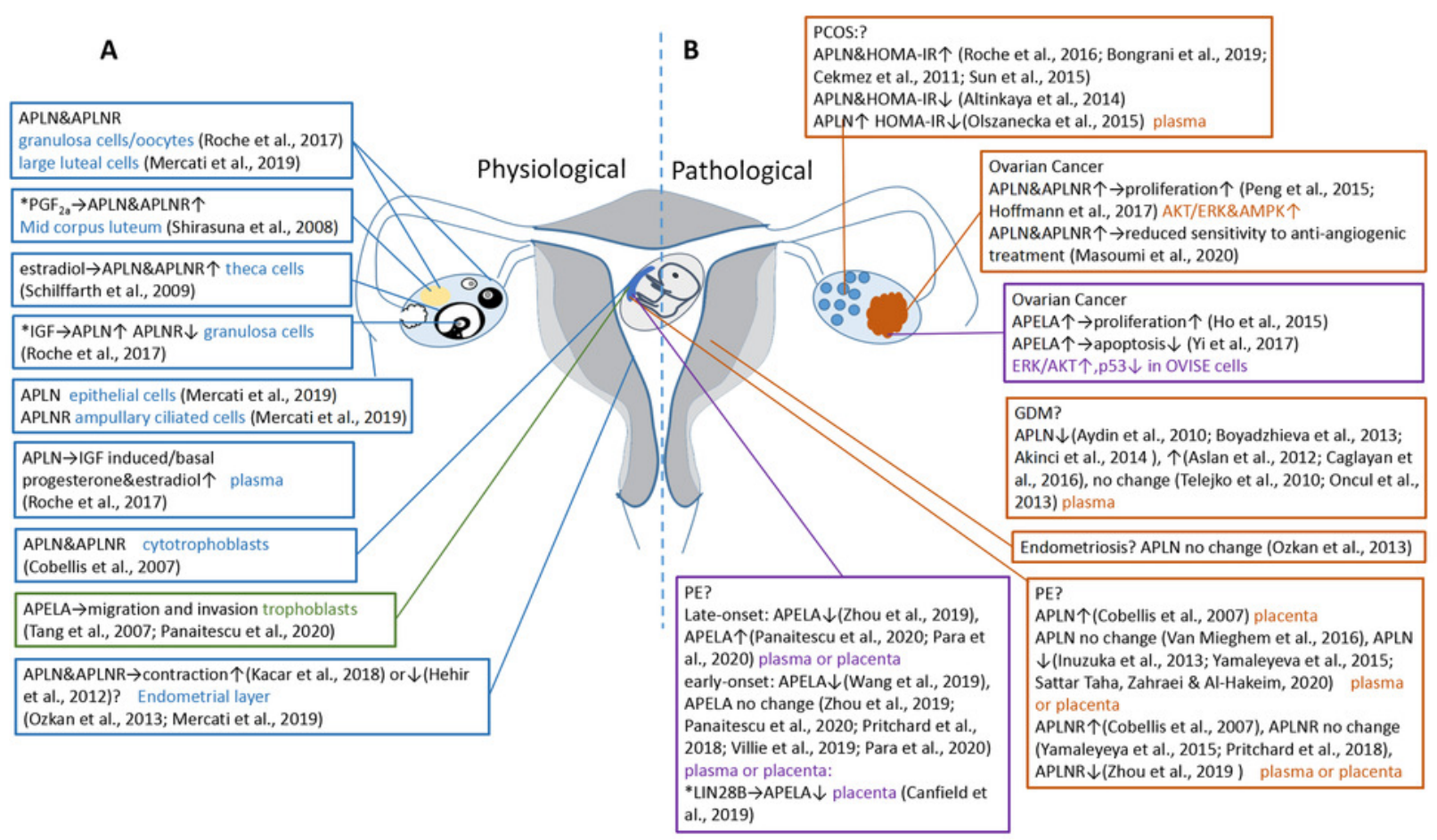




\section{Figure 2}

Intracellular signaling pathways and physiological functions of APLN and APELA.

(A) Both APLN (in blue) and APELA (in orange) can classically activate Gai/o and Gaq/11 mediated intracellular transduction via binding to their common receptor APLNR. (B) Noncoding APELA binds to hnRNPL and promotes p53-mediated cell apoptosis. (C) APELA also stimulates PI3K-independent NODAL/TGF $\beta$ signal through alternative receptors in hESCs. AC, adenylate cyclase; eNOS, endothelial nitric oxide synthase; IncRNA, long non-coding RNA; hnRNPL, heterogeneous nuclear ribonucleoprotein $\mathrm{L}$.

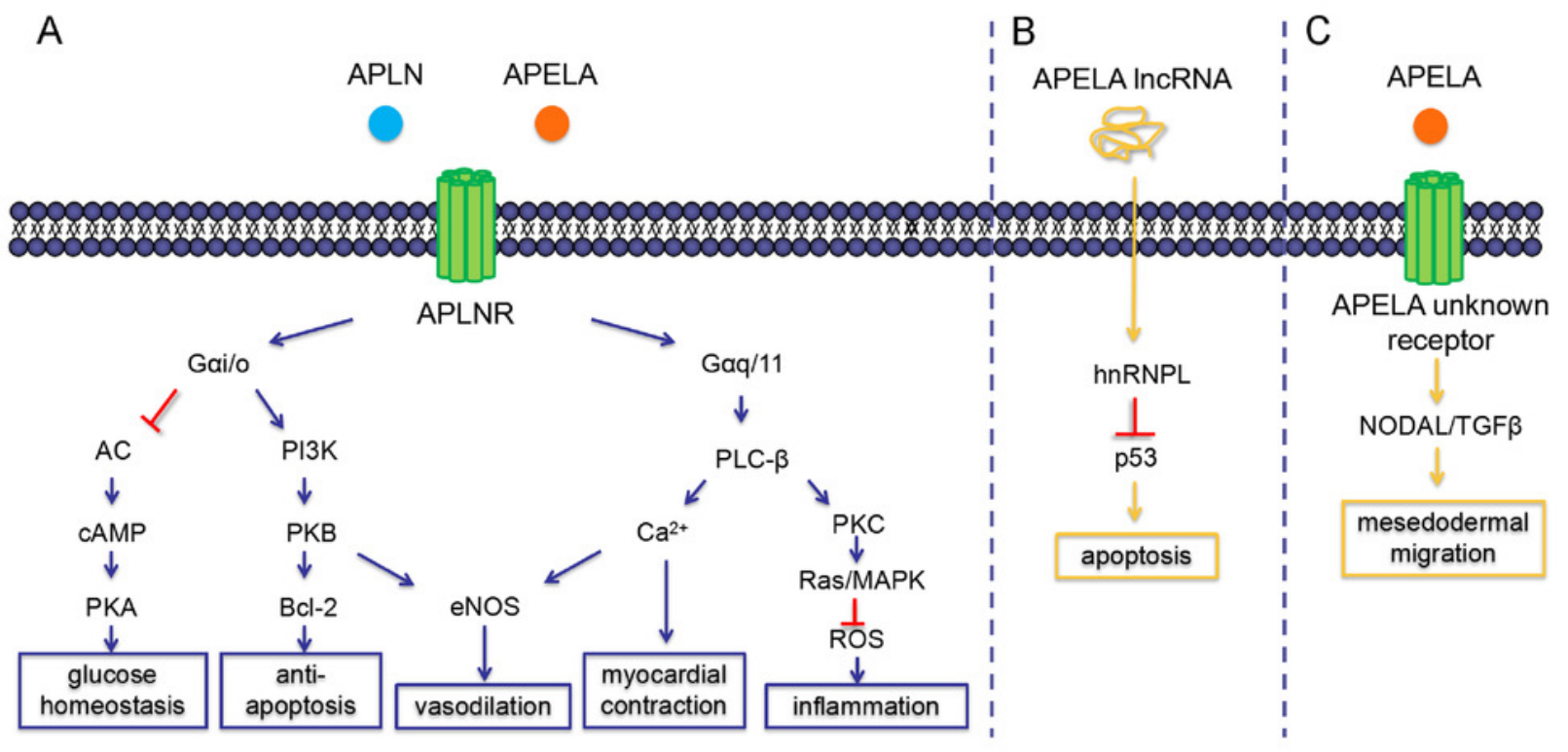




\section{Table $\mathbf{1}$ (on next page)}

Summary of studies about the expressional changes of APLN and APELA in the polycystic ovary syndrome (PCOS), Ovarian cancer (OvCa), preeclampsia (PE) and gestational diabetes mellitus (GDM).

For each study, the authors, year, disease type, species, samples, molecule, sample size (No. of cases and controls), analyzed expression and significance were listed. There would be a significance when $p<0.05$, and $p$ values were listed in the table (if given). The table was ordered by diseases, molecules and year of publication. PCOS, polycystic ovary syndrome; OvCa, ovarian cancer; PE, preeclampsia; GDM, gestational diabetes mellitus; NA, not available. 
1 Table 1: Summary of studies about the expressional changes of APLN and APELA in the polycystic ovary syndrome (PCOS), Ovarian cancer (OvCa), preeclampsia (PE) and gestational diabetes mellitus (GDM).

\begin{tabular}{|c|c|c|c|c|c|c|c|c|c|c|}
\hline authors & year & $\begin{array}{l}\text { disease } \\
\text { type }\end{array}$ & species & samples & molecule & $\begin{array}{l}\text { No. of } \\
\text { cases }\end{array}$ & $\begin{array}{l}\text { No. of } \\
\text { controls }\end{array}$ & $\begin{array}{l}\text { analyzed } \\
\text { expression }\end{array}$ & significance & notes \\
\hline $\begin{array}{l}\text { Cekmez } \\
\text { et al. }\end{array}$ & 2011 & PCOS & human & plasma & APLN & 48 & 37 & protein & $\begin{array}{l}\text { higher in } \\
\text { patients } \\
(\mathbf{p}<\mathbf{0 . 0 0 1 )}\end{array}$ & $\begin{array}{l}\text { positive } \\
\text { with } \\
\text { HOMA- } \\
\text { IR }\end{array}$ \\
\hline $\begin{array}{l}\text { Altinkaya } \\
\text { et al. }\end{array}$ & 2014 & PCOS & human & plasma & APLN & 45 & 45 & protein & $\begin{array}{l}\text { lower in } \\
\text { patients }\end{array}$ & $\begin{array}{l}\text { positive } \\
\text { with } \\
\text { HOMA- } \\
\text { IR }\end{array}$ \\
\hline $\begin{array}{l}\text { Olszaneck } \\
\text { a- } \\
\text { Gliniano } \\
\text { wicz et al. }\end{array}$ & 2015 & PCOS & human & plasma & APLN & 87 & 67 & protein & $\begin{array}{l}\text { lower in } \\
\text { patients }\end{array}$ & $\begin{array}{l}\text { negative } \\
\text { with } \\
\text { HOMA- } \\
\text { IR } \\
(\mathbf{p}<0.001)\end{array}$ \\
\hline Sun et al. & 2015 & PCOS & human & plasma & APLN & 63 & 40 & protein & $\begin{array}{l}\text { higher in } \\
\text { patients } \\
(\mathbf{p}<0.05)\end{array}$ & $\begin{array}{l}\text { positive } \\
\text { with } \\
\text { HOMA- } \\
\text { IR }\end{array}$ \\
\hline $\begin{array}{l}\text { Roche et } \\
\text { al. }\end{array}$ & 2016 & PCOS & human & tissue & $\begin{array}{l}\text { APLN } \\
\text { and } \\
\text { APLNR }\end{array}$ & 65 & 60 & $\begin{array}{l}\text { mRNA } \\
\text { and } \\
\text { protein }\end{array}$ & $\begin{array}{l}\text { higher in } \\
\text { patients } \\
(\mathbf{p}<0.05)\end{array}$ & \\
\hline $\begin{array}{l}\text { Bongrani } \\
\text { et al. }\end{array}$ & 2019 & PCOS & human & $\begin{array}{l}\text { plasma } \\
\text { and } \\
\text { tissue }\end{array}$ & $\begin{array}{l}\text { APLN } \\
\text { and } \\
\text { APLNR }\end{array}$ & 23 & $27(+28)$ & $\begin{array}{l}\text { mRNA } \\
\text { and } \\
\text { protein }\end{array}$ & $\begin{array}{l}\text { higher in } \\
\text { patients } \\
(\mathbf{p}<0.01)\end{array}$ & \\
\hline Yi et al. & 2017 & OvCa & human & tissue & APELA & NA & NA & $\begin{array}{l}\text { mRNA } \\
\text { and } \\
\text { protein }\end{array}$ & $\begin{array}{l}\text { higher in } \\
\text { patients }\end{array}$ & \\
\hline $\begin{array}{l}\text { Neelakant } \\
\text { an et al. }\end{array}$ & 2019 & OvCa & human & tissue & APLNR & NA & NA & $\begin{array}{l}\text { mRNA } \\
\text { and } \\
\text { protein }\end{array}$ & $\begin{array}{l}\text { higher in } \\
\text { patients } \\
(\mathbf{p}<0.05)\end{array}$ & \\
\hline $\begin{array}{l}\text { Panaitesc } \\
\text { u et al. }\end{array}$ & 2018 & EOPE & human & plasma & APELA & 56 & 59 & protein & $\begin{array}{l}\text { no } \\
\text { difference }\end{array}$ & \\
\hline $\begin{array}{l}\text { Pritchard } \\
\text { et al. }\end{array}$ & 2018 & EOPE & human & plasma & $\begin{array}{l}\text { APELA } \\
\text { and } \\
\text { APLNR }\end{array}$ & 32 & 32 & mRNA & $\begin{array}{l}\text { both no } \\
\text { difference }\end{array}$ & \\
\hline $\begin{array}{l}\text { Villie et } \\
\text { al. }\end{array}$ & 2019 & EOPE & human & plasma & APELA & 12 & 14 & protein & $\begin{array}{l}\text { no } \\
\text { difference }\end{array}$ & \\
\hline $\begin{array}{l}\text { Wang et } \\
\text { al. }\end{array}$ & 2019 & EOPE & human & placenta & APELA & 30 & 30 & $\begin{array}{l}\text { mRNA } \\
\text { and } \\
\text { protein }\end{array}$ & $\begin{array}{l}\text { lower in } \\
\text { patients } \\
(\mathbf{p}<0.0001)\end{array}$ & \\
\hline $\begin{array}{l}\text { Zhou et } \\
\text { al. }\end{array}$ & 2019 & EOPE & human & placenta & $\begin{array}{l}\text { APELA } \\
\text { and } \\
\text { APLNR }\end{array}$ & 6 & 11 & $\begin{array}{l}\text { mRNA } \\
\text { and } \\
\text { protein }\end{array}$ & $\begin{array}{l}\text { APELA no } \\
\text { difference; } \\
\text { APLNR } \\
\text { both lower } \\
\text { in patients } \\
(\mathbf{p}<0.05)\end{array}$ & \\
\hline $\begin{array}{l}\text { Zhou et } \\
\text { al. }\end{array}$ & 2019 & EOPE & human & plasma & APELA & 15 & 15 & protein & $\begin{array}{l}\text { no } \\
\text { difference }\end{array}$ & \\
\hline Para et al. & 2020 & EOPE & human & plasma & APELA & 54 & 56 & protein & $\begin{array}{l}\text { no } \\
\text { difference }\end{array}$ & \\
\hline
\end{tabular}




\begin{tabular}{|c|c|c|c|c|c|c|c|c|}
\hline $\begin{array}{l}\text { Panaitesc } \\
\text { u et al. }\end{array}$ & 2018 & LOPE & human & plasma & $\begin{array}{l}\text { APELA } \\
\text { and } \\
\text { APLNR }\end{array}$ & 57 & 60 & protein \\
\hline
\end{tabular}

APELA

higher in

patients

(p=0.01);

APLNR no

difference

\begin{tabular}{|c|c|c|c|c|c|c|c|c|}
\hline $\begin{array}{l}\text { Zhou et } \\
\text { al. }\end{array}$ & 2019 & LOPE & human & placenta & $\begin{array}{l}\text { APELA } \\
\text { and } \\
\text { PPLNR }\end{array}$ & 14 & 11 & $\begin{array}{l}\text { mRNA } \\
\text { and } \\
\text { nrotein }\end{array}$ \\
\hline
\end{tabular}

APELA

both lower

in patients

(p<0.01);

APLNR

protein

lower in

patients

$(\mathbf{p}<0.01)$

$\begin{array}{lllllllll}\text { Zhou et } & 2019 & \text { LOPE } & \text { human } & \text { plasma } & \text { APELA } & 22 & 15 & \text { protein }\end{array}$

$\begin{array}{lllllllll}\text { al. } & 2019 & \text { LOPE } & \text { human } & \text { plasma } & \text { APELA } & 22 & 15 & \text { protein } \\ (\mathbf{p}<0.01)\end{array}$

$\begin{array}{lllllllll}\text { Para et al. } & 2020 & \text { LOPE } & \text { human } & \text { plasma } & \text { APELA } & 52 & 52 & \text { protein }\end{array}$

$(\mathbf{p}<\mathbf{0 . 0 0 1})$

\begin{tabular}{|c|c|c|c|c|c|c|c|c|c|}
\hline $\begin{array}{l}\text { Cobellis } \\
\text { et al. }\end{array}$ & 2007 & PE & human & placenta & $\begin{array}{l}\text { APLN } \\
\text { and } \\
\text { APLNR }\end{array}$ & 15 & 15 & protein & $\begin{array}{l}\text { APLN and } \\
\text { APLNR } \\
\text { expression } \\
\text { both highe } \\
(p<0.05)\end{array}$ \\
\hline $\begin{array}{l}\text { Inuzuka } \\
\text { et al. }\end{array}$ & 2013 & PE & human & placenta & APLN & NA & NA & $\begin{array}{l}\text { mRNA } \\
\text { and } \\
\text { protein }\end{array}$ & $\begin{array}{l}\text { mRNA } \\
\text { lower in } \\
\text { patients } \\
(p<0.05)\end{array}$ \\
\hline
\end{tabular}

APLN lower in patients

(only

protein

p $<0.05$ ),

Yamaleye

2015 P

$\begin{array}{ll}\text { human placenta } & \text { APLN } \\ \text { and }\end{array}$

20

22

mRNA

and

APLNR no

difference

(both

mRNA and

protein)

Van

Miegh

2016

PE

human

plasma

APLN

8

10

mRNA

no

difference

used antihyper tensive

treatment

Sattar

Taha,

Zahraei

2020

PE

human plasma APLN

60

30

protein

lower in patients $(\mathbf{p}<\mathbf{0 . 0 1})$

Hakeim

Aydin

2010 GDM

human breast

APLN

10

10

protein

lower in patients

Telejko et

2010 GDM

APLN

al.

(1)

$\begin{array}{ll}\text { APLNR } & \text { and }\end{array}$

10

mRNA

no

difference

Aslan et

2012 GDM

plasma

and

cord
blood

APLN

30

30

protein

higher in patients

$(p=0.001)$

Boyadzhi

2013 GDM

human plasma APLN

127

109

protein

lower in patients $(p=0.009)$ 


\begin{tabular}{lllllllll}
\hline $\begin{array}{l}\text { Oncul et } \\
\text { al. }\end{array}$ & 2013 & GDM & human & $\begin{array}{l}\text { plasma } \\
\text { and } \\
\text { cord } \\
\text { blood }\end{array}$ & APLN & 24 & 21 & $\begin{array}{l}\text { protein } \\
\text { no } \\
\text { difference }\end{array}$ \\
$\begin{array}{l}\text { Akinci et } \\
\text { al., }\end{array}$ & 2014 & GDM & human & plasma & APLN & 141 & 49 & protein \\
lower in \\
patients \\
(p<0.001)
\end{tabular}
For each study, the authors, year, disease type, species, samples, molecule, sample size (No. of cases and controls), analyzed
4 expression and significance were listed. There would be a significance when p $<0.05$, and $p$ values were listed in the table (if given).

5 The table was ordered by diseases, molecules and year of publication. PCOS, polycystic ovary syndrome; OvCa, ovarian cancer; 6 PE, preeclampsia; GDM, gestational diabetes mellitus; NA, not available. 